\title{
Novinky v léčbě obezity
}

\author{
MUDr. Pavol Holéczy, CSc.
}

Katedra chirurgických oborů, LF Ostravské univerzity, Ostrava

Chirurgické oddělení, Vítkovická nemocnice, a.s., Ostrava

\begin{abstract}
Obezita je fenoménem moderní doby. S ní jsou spojené četné komorbidity. Postihuje prakticky celou planetu. Léčba obezity, konzervativní či chirurgická, cilí dnes nejen na redukci hmotnosti, ale také, nebo zejména, na pozitivní ovlivnění komorbidit. Tradiční postupy jsou dobře známy jak laické, tak odborné veřejnosti. Nově se definují formy a trvání fyzické aktivity. Novější možnosti ve farmakoterapii poskytují medikamenty nedávno uvedené na český trh (Mysimba ${ }^{\oplus}$ a Saxenda®). Nové chirurgické postupy se zaměřují také nejen na redukci hmotnosti, ale zejména na změnu skladby těla a ovlivnění komorbidit. Endoskopické postupy, kterých se objevuje celá řada, zatím nedosahuji efektivity a trvanlivosti operačních výkonů.
\end{abstract}

Klíčová slova: obezita, komorbidita, pohyb, farmakoterapie, endoskopie, chirurgie.

\section{Novelties in the treatment of obesity}

Obesity is a phenomenon of modern times. It is associated with numerous comorbidities. It affects virtually the entire planet. Treatment of obesity, both conservative and surgical, aims not only at weight reduction, but also, or, in particular, on the positive effect of comorbidities. Traditional procedures are well known to both lay and professional public. There are new definition of type and duration of physical acitivty. Newer possibilities in drug therapy provide recently introduced drugs on the Czech market (Mysimba ${ }^{\oplus}$ and Saxenda ${ }^{\oplus}$ ). New surgical procedures also focus not only on weight reduction, but also on changes in body composition and the influence on comorbidities. Endoscopic procedures, which recently emerged, do not achieve the effectiveness and durability of surgical procedures, yet.

Key words: obesity, comorbidity, physical aktivity, pharmacotherapy, endoskopy, surgery.

\section{Úvod}

Obezita je fenoménem moderní doby. WHO uvádí, že v roce 2016 mělo 39 \% mužů a 39 \% žen ve věku 18 let nadměrnou hmotnost (BMI $\left.\geq 25 \mathrm{~kg} / \mathrm{m}^{2}\right)$ a $11 \%$ mužů a $15 \%$ žen bylo obézních (BMI $\left.\geq 30 \mathrm{~kg} / \mathrm{m}^{2}\right)$. Takže téměř 2 miliardy dospělých lidí na celém světě mělo nadměrnou hmotnost, z nichž více než půl miliardy byli obézní. V roce 1975 bylo obézních jen 3 \% mužů a $6 \%$ žen a nadměrnou hmotnost mělo jen 20\% mužů a necelých 23 \% žen (1). Nárůst nadměrné hmotnosti a obezity je tedy evidentní. Je obecně známo, že s obezitou jsou spojeny další nemoci, které s ní bud’ souvisí, či jsou jí do jisté míry vyvolány, nebo obezita zhoršuje jejich průběh. Nadměrná hmotnost a obezita jsou pátou vedoucí príčinou pro úmrtí celosvětově a čtvrtým nejrizikovějším faktorem pro poruchy zdraví a úmrtí v Evropě (2). Deitel (3) tohle celosvětové rozšírení obezity a s tím související hrozbu nazývá termínem "globezita“. Spojení obezity a jejího nárůstu celosvětově, jde ruku v ruce s nárůstem počtu pacientů s diabetes mellitus 2 . typu (DMT2) a dalo základ vzniku termínu „diabezita” (4). Prevalence diabetes mellitus vrostla z 3,3\% v roce 1995 na 6,4% v r. 2010 a prognóza pro rok 2030 je nárůst až na 7,7 \% (4). Je proto nutné vnímat obezitu jako komplexní problém. I když existují různá doporučení odborných organizací zabývajících se léčbou obezity jak konzervativní $(5,6)$, tak chirurgickou (7), samotná doporučení k zastavení nárůstu počtu obézních nestačí. Je potřeba věnovat neustále tomuto problému pozornost v co nejširší míre a týká se to prakticky všech medicínských specializací. Cílem této práce je poskytnout informace o tom, co je dnes nového zejména v léčbě obezity a s ní spojených komorbidit.

\section{Nemedikamentózní léčba}

I když je obecně znám význam pohybových aktivit, kognitivně behaviorálních postupů, a nutričních opatření, je nutno dostat více do povědomí laické i odborné veřejnosti skutečně odborné aktivity, které vykazuji standardní výsledky a jsou zárukou, že nedojde k poškození zdraví. Naopak, kromě snížení hmotnosti přinesou i konzervativní postupy 
zlepšení stavu přidružených onemocnění, která obezitu provázejí, nebo jsou dokonce obezitou podmiňována, nebo zhoršována. Relativně početný seznam odborných pracovišt zabývajících se léčbou obezity $v$ dětském i dospělém věku, včetně pracovišt bariatrické/metabolické chirurgie je možné najít na webové stránce České obezitologické společnosti www.obesitas.cz (8). Význam pohybové aktivity zmiňují i poslední doporučení Americké asociace pro léčbu diabetu (ADA) (9). Kombinace diety, pohybové aktivity a behaviorální terapie přináší redukci víc než 5 \% celkové tělesné hmotnosti. Fyzická aktivita je prevencí opětovného nárůstu hmotnosti. Přibývá poznatků, že je vhodnější být aktivní častěji v kratších časových intervalech než podstupovat dlouhodobou zátěž (10). Doporučená dávka fyzické aktivity se pohybuje mezi 225 až 420 minutami týdně (11). Z diet se v poslední době favorizuje nízkosacharidová dieta, ale výsledky metaanalýzy Churuangsuka tuto preferenci jednoznačně nepotvrzují (12).

\section{Medikamentózní léčba}

Indikací farmakoterapie je selhání nefarmakologické léčby vedené po dobu 3 měsíců u pacientů s BMI $\geq 30$ nebo u pacientů s BMl $\geq 27$, jsou-li prítomna kardiovaskulární a metabolická rizika související s obezitou. Farmakoterapie obezity se nedoporučuje u pacientů nad 65 let a u dětí. U pacientů nad 70 let data chybí. Kontraindikace vyplývají z mechanismu působení jednotlivých farmak a s ním spojeným možným výskytem nežádoucích účinků (13). Současnými dostupnými antiobezitiky v ČR jsou orlistat, fentermin a novinkami je kombinace naltrexon + bupropion (Mysimba ${ }^{\oplus}$ ) a od listopadu 2018 liraglutid (Saxenda®). Jelikož farmakologická léčba není právě „mým šálkem kávy“ dovolím si v této části textu převzít podstatnou část z práce prim. MUDr. Šrámkové (14), kterou považuji za přehlednou a srozumitelnou.

\section{Orlistat}

Jde o známé antiobezitikum (Xenical ${ }^{\circledR}$ ). Je inhibitorem střevní lipázy - inhibuje část účinku enzymů trávicích tuky. Redukce hmotnosti se dosahuje sníženým vstřebáváním tuků ze střeva, a to asi o 30 \% při dávce 120 mg (25 \% při dávce 60 mg), čímž se sníží kalorický obsah jídla o cca 600 kJ/den. Průměrný pokles hmot- nosti je 5,5kg/rok. Dochází i k významnému zlepšení v lipidovém spektru, zlepšení citlivosti k inzulinu, poklesu glykovaného hemoglobinu a u obézních nediabetiků dochází k významnému snížení rizika vzniku diabetu 2. typu o $37 \%$. Léky Ize podávat dlouhodobě i po dobu 4 let, minimálně však 3 měsíce k zajištění efektu. Při srovnání samotné diety je redukcí hmotnosti spolu s Xenicalem dosaženo i zlepšení kardiovaskulárních rizikových faktorů, jako jsou hypertenze a patologie lipidového spektra.

\section{Fentermin}

Fentermin je v ČR registrován jako Adipex ret $^{\oplus} 15$ mg v tabletách. $\vee$ ČR je možnost preskripce omezena na předpis na opiátový recept s modrým pruhem. Důvodem velkého omezení bylo zneužívání látky k výrobě návykové látky pervitinu. U některých pacientů, kteří dostávali anorektika tohoto typu, byly zaznamenány prípady závažné, často fatální pulmonální hypertenze. Dlouhodobá léčba tímto prípravkem je spojena s rizikem farmakologické tolerance, závislosti a abstinenčními príznaky.

\section{Naltrexon s bupropionem}

Bupropion - aktivátor proopiomelanokortinové osy jako antidepresivum dohromady s antagonistou opioidních receptorů naltrexonem vede spolu s kognitivně behaviorální terapií k redukci hmotnosti. Předpokládá se stimulace melanokortinové osy a synergické efekty na systém mezencefalu. Od roku 2015 je též schválena Evropskou agenturou pro léčivé prípravky (EMA) jako Mysimba 8 mg/90 mg prolonged-release tablets. Od druhé poloviny roku 2016 je k dostání v zemích EU. Lék je určen k redukci váhy pacientů s BMI $\geq 30 \mathrm{a} \geq 27$ s komorbiditami. Na její oblibě bude mít bezesporu vliv i to, že obě látky samostatně jsou již na trhu více než 30 let a nemají zásadní nežádoucí účinky.

Bupropion byl primárně určen k terapii depresivních onemocnění a také k odvykání kouření. Snižuje příjem potravy - inhibuje zpětné vychytávání dopaminu a noradrenalinu + aktivuje hypotalamickou proopiomelanokortin-anorexigenní osu, potlačuje chut k jídlu a zvyšuje kontrolu nad jídlem.

Naltrexon je opioidní antagonista užívaný při léčbě závislosti na opiodech a alkoholu. Snižuje príjem potravy - inhibuje opioidní neurony tlumící hypotalamickou melanokortinovou anorexigenní osu + inhibuje „odměňovací ( ward") systém v CNS.

Ve studiích byla průměrná redukce 9,3\% hmotnosti $(8,2 \mathrm{~kg})$ a zmenšení obvodu pasu o 6,2 cm za 56 týdnů léčby. Více než 50 \% diabetiků dosáhlo glykHb $<7 \%$. Došlo ke zmenšení obvodu pasu, snižení hladiny triglyceridů, LDL, HbA1c, glykemie, diastolického tlaku krve a zvýšení HDL cholesterolu. Lék nemá vliv na tepovou frekvenci. Zatím nejčastějšími nežádoucími účinky se jeví nauzea (32%), zácpa (19\%), cefalea (18\%), zvracení (11 \%), závrat’ a sucho v ústech. Kontraindikací jsou těžké psychiatrické poruchy, epilepsie, léková či alkoholová závislost, současné podávání léků se stejným složením či MAO (monoaminooxidáza), podávání dětem.

\section{Liraglutid}

První GLP (glukagon-like peptid) - 1 analog schválený FDA v roce 2014 k léčbě obezity je k dispozici pod názvem Saxenda®. Schválení v Evropě agenturou EMA proběhlo v lednu 2015, v ČR je preparát schválen Státním ústavem pro kontrolu léčiv až nyní a možnost preskripce je možná od listopadu 2018. Jedná se o injekční preparát, který se podává 1× denně subkutánně. Má prakticky dvojnásobné dávkování než při léčbě diabetu. Saxenda obsahuje v jedné dávce 3,0 ml liraglutidu. V léčbě diabetu se používají GLP-1 analoga již běžně. Tyto látky tlumí zvýšenou sekreci glukagonu, zvyšují sekreci inzulinu, potlačují apoptózu beta buněk pankreatu a zároveň navozují pocit sytosti v mozku, snižují chut k jídlu, zpomalují vyprazdňování žaludku, zvyšují pocit plnosti a snižuji príjem potravy. V bílé tukové tkáni snižují ukládání tuku stimulací lipolýzy a inhibicí lipogeneze. Při redukci váhy nedochází ke snížení klidového energetického výdeje. Tato tzv. inkretinová léčba má kromě antidiabetického působení i řadu dalších potenciálně velmi zajímavých předpokládaných kardioprotektivních a neuroprotektivních účinků. Snižuje krevní tlak a má pozitivní vliv na lipidové parametry a v některých studiích též snižuje subklinickou zánětlivou reakci. Inkretinová mimetika vedou k trvalé redukci hmotnosti diabetiků v průměru o 2-5 kg s dokumentovaným efektem přetrvávajícím po dobu 2 let. GLP-1 agonisté jsou efektivní k navození a udržení váhového úbytku po dobu 104 týdnů s dobrou tolerovaností a bezpečností. Z nežádoucích účinků je uváděna nauzea $40 \%$, zvracení $16 \%$, průjem, zácpa, bolesti břicha, 
nazofaryngitida, cefalea, únava, atralgie a také sporadický výskyt pankreatitidy.

Kontraindikací podání je medulární karcinom štítné žlázy nebo pankreatitida v anamnéze.

Efekt terapie je posuzován dle FDA po 16 týdnech, kdy by měl být efekt redukce $\geq 4 \%$ původní hmotnosti, dle EMA je kontrola po 12 týdnech a úbytek váhy by měl být $\geq 5 \%$ původní hmotnosti.

Uchování pera pred použitím je doporučeno v chladničce při $2-8^{\circ} \mathrm{C}$. Při aplikaci pak uchování pera v pokojové teplotě mezi 15 a $30^{\circ} \mathrm{C}$ nebo $v$ chladničce.

\section{Glifloziny}

Další novou lékovou skupinou k léčbě diabetu, ale využívající synergického efektu jak snížení glykemie a glykovaného hemoglobinu, tak hmotnosti, jsou glifloziny. Glifloziny jsou inhibitory SGLT2 receptoru v proximálním tubulu. Vlastním efektem je částečné zablokování zpětného vstřebávání glukózy z primární moči v proximálním tubulu glomerulu. Tím dochází k arteficiální glukosurii. Nadbytečná glukóza je vyloučena do moči ( 70 g/den = 1200 kJ/den). Množství vyloučené glukózy odpovídá typu preparátu. Od roku 2015 jsou k dispozici dapagliflozin (Forxiga ${ }^{\oplus}$ ), canagliflozin (Invokana ${ }^{\circledR}$, empagliflozin (Jardiance ${ }^{\circledast}$ ). Dávkování je 1× denně kdykoli během dne. Schváleny EMA i FDA jsou dále kombinované preparáty s metforminem: dapagliflozin/metformin (Xigduo ${ }^{\oplus}$ ), canagliflozin/metformin $\left(\right.$ Vokanamet $\left.^{\oplus}\right)$, empagliflozin/ metformin (Synjardy ${ }^{\circledast}$ ). Průměrná redukce hmotnosti je 2-3 kg/rok. Je také třeba zmínit, že díky svému účinku dochází ke zvýšenému odpadu glukózy do moči, a tedy pozitivnímu močovému nálezu na obsah cukru. S tím souvisí u malého procenta pacientů výskyt urogenitálních infekcí, které obvykle dobře reagují na běžnou léčbu a nejsou důvodem k přerušení antidiabetické terapie. V léčbě obezity jsou úspěšně zkoušeny léky na principu inhibitorů SGLT1 + SGLT2 - působící zejména v tračníku, nyní v poslední fázi klinických studií (14).

\section{Bariatrická/metabolická chirurgie}

Chirurgie závažné obezity je známá již desetiletí pod pojmem bariatrická chirurgie. Cílem těchto výkonů byla především zásadní redukce nadměrné hmotnosti. Na začátku nového milé- nia se dostává do povědomí nový termín - metabolická chirurgie. Nejde o jiné typy operací, ale termín metabolická chirurgie zdůrazňuje význam chirurgické intervence nejen na redukci hmotnosti, ale také, nebo zejména, na význam v ovlivnění komorbidit s obezitou spojených, především diabetes mellitus 2. typu. Vše zásadní v této problematice, včetně standardních operací uvádějí Evropská mezinárodní doporučení pro metabolickou a bariatrickou chirurgii (7).

\section{Nové postupy}

$\checkmark$ posledních dvou letech se objevují nové chirurgické i endoskopické intervence, které se zaměřují především na zlepšení metabolických onemocnění, a ovlivnění hmotnosti není u nich primárním cílem. V roce 2017 predstavil Melissas (15) jednoduchou operaci, príi níž vytvořil anastomózu mezi proximálním jejunem a distálním ileem (100 cm z každé strany). Část potravy prochází touto spojkou a část potravy postupuje standardní cestou celým tenkým střevem. Žádná část tenkého střeva není operací vyřazena z pasáže a nedochází k atrofii klků sliznice tenkého střeva. $V$ souboru byli pacienti s BMI od 28 do 32 kg/m², kteří měli DMT2 a cílem bylo zlepšení cukrovky. U všech pacientư ve studii došlo ke zlepšení cukrovky a snížení množství potřebných léků. $\vee$ témže roce publikoval výsledky experimentální práce i výsledky ve skupině 15 operovaných dospělých Fried (16). Operaci nazývá parciální jejunální diverze (PJD) ve shodě s Machytkou (17). Fried podobným způsobem jako Melissas našívá jejunoileální spojku. Všichni pacienti v souboru byli diabetici a u všech zaznamenali zlepšení sacharidového metabolismu. Hmotnostní úbytek byl menší než bývá pravidlem u standardních výkonů. Ve stejném čase publikoval výsledky své studie Machytka (18), který ve snaze minimalizovat zátěž pacienta zavádí endoskopicky do jejuna a ilea magnetické osmihrany. Ty se spojí přes stěnu tenkého střeva a tlakem na ni během několika dní vytvoři arteficiálně intestinální píštěl a tím vlastně jejunoileální anastomózu. Zatím byly výkony provedeny v celkové anestezii pod laparoskopickou kontrolou, po standardizaci intervence je cílem čistě endoskopický výkon bez nutnosti celkové anestezie. Také v této studii došlo u pacientů k významnému zlepšení sacharidového metabolismu. Redukce celkové
Obr. 1. Endobarrier - polyetylenový duodenojejunálnírukáv

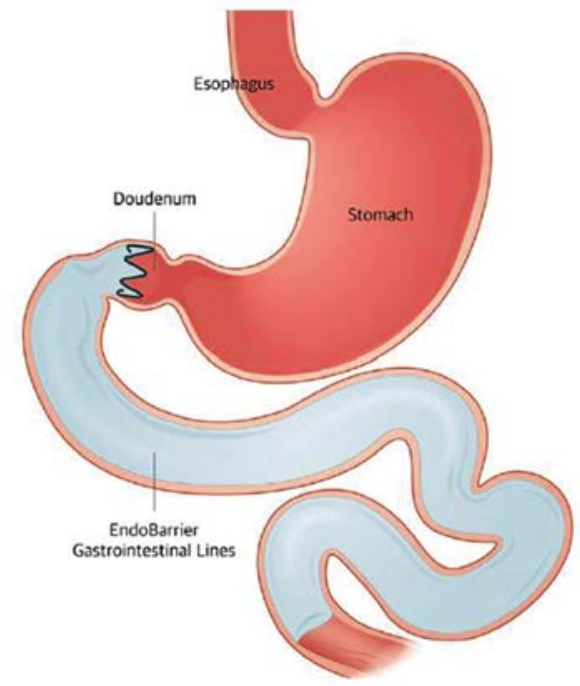

Obr. 2. Ezofago-gastro-jejunální rukáv

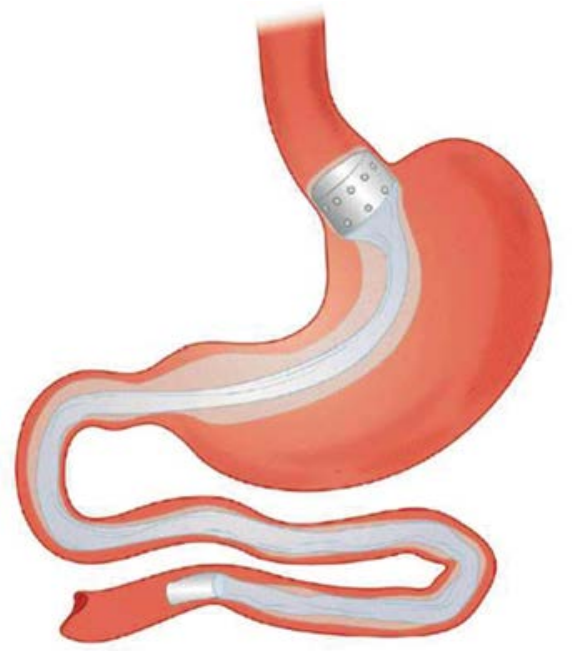

Obr. 3. Transpylorickékyvadlo

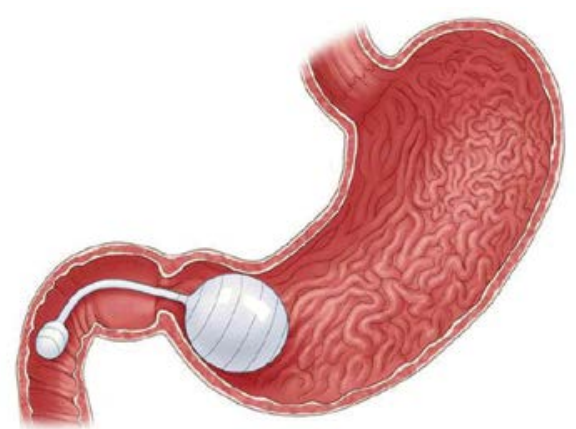

hmotnosti byla dokonce približně o 5 \% lepší než v práci Frieda. Nutno říci, že jde zatím o experimentální výkon. Kromě studie Melissase, který hodnotí výsledky za tři roky, uvádějí druhé dvě studie výsledky za rok, což je ještě krátký čas sledování. Ačkoliv jsou začátky optimistické, na seriózní zhodnocení prínosu nových postupů bude zapotřebí dlouhodobější sledování na větším souboru pacientů. 


\section{MEZIOBOROVÉ PŘEHLEDY}

\section{NOVINKY V LÉČCĚ OBEZITY}

\section{Endoskopické postupy}

Přehled současných endoskopických metod podává Dargent v r. 2016 (18). Za zmínku stojí uvést zejména gastrický balon nazvaný Obalon, který se spolkne jako malá kapsle na spojovací hadičce, a naplní se bez pomoci endoskopie. Je možné tak umístit do žaludku až 3 balony. Odstranit se musí endoskopicky za 6 měsíců. Z pohledu chirurga je optimální použití gastrického balonu u velmi rizikových pacientů v prípravě k metabolické operaci. Naděje se vkládají také do endoskopických výkonů, které zmenšují objem žaludku, např. Systém Apollo overstich, kde se endoskopicky nařasí žaludek transmurálně naloženými stehy. Nevýhodou je riziko rozvolnění stehů. Naděje se vkládali do tzv. duodenojejunálního rukávu. Jde o polyetylenový rukáv ukotvený v oblasti pyloru a zasahující až do proximálního jejuna. Tim se zamezí kontaktu potravy se sliznicí duodena. Napodobují se tak anatomické a patofyziologické změny po gastrickém bypassu (obrázek 1) (19). Možnost použití ještě delšího plastového rukávu uvádí Park (15). Tenhle rukáv se fixuje na proximálním konci v ezofagokardiálním přechodu a konec ru-

\section{LITERATURA}

1. WHO Obesity and overweight, Dostupné z: https://www. who.int/gho/ncd/risk_factors/overweight_text/en/

2. Uerlich MF, Yumuk V, Finer $N$, et al. Obesity management in Europe: Current status and objectives for the future. Obes Facts 2016; (9): 273-283.

3. Deitel M. The International Obesity Task Force and "globesity". Obes surg 2002; 12(5): 613-614.

4. Farag YM, Gabala MR. Diabesity: an overview of a rising epidemic. Nephrol Dial Transplant 2011; 26(1): 28-35.

5. Ryan DH, Kahan S. Guideline Recommendations for Obesity Management. Med Clin North Am 2018; 102(1): 49-63. 6. YumukV, Tsigos C, Fried M, Schindler K, Busetto L, Micic D, Toplak H. European Guidelines for Obesity Management in Adults Obes Facts 2015; 8(6): 402-424.

7. Fried M, Yumuk V, Oppert J-M, e al. Interdisciplinary European quidelines on metabolic and bariatric surgery. Obes Facts 2013; 6: 449-468.

8. Seznam obezitologických pracovišť v České republice. Dostupné z: http//www.obesitas.cz

9. ADA: Obesity Management for the Treatment of Type 2 kávu sahá do proximálního jejuna. Tento výkon se nazývá gastroduodenojejunální bypassový rukáv (obrázek 2) (19). Problematické u uvedených implantátů je to, že mohou být in situ jen kolem 6 měsíců a poté musí byt extrahovány. Na základě našich zkušeností po extrakci bandáže, nebo cíleném rozvolnění plikace žaludku, si dovolíme tvrdit, že efekt na redukci hmotnosti i metabolický efekt nebudou přetrvávat dlouhodobě. Další novinkou je tzv. transpylorické kyvadlo (obrázek 3) (20). Endoskopicky jen v sedaci se zavádí dvojitý balón, který je spojený přes pylorus a pohybem intermitentně pylorus uzavírá. I když jsou první výsledky pozitivní, jde jen o velmi krátké období sledování, a bude nutné delší pozorování s větším počtem pacientů. Poslední z endoskopických metod, kterou je potřeba zmínit, je aspirační léčba. Multicentrickou studii uvádějící výsledky v 1-4letém sledování publikoval Nyström (21). V souboru 201 pacientů bylo dosaženo signifikantní redukce hmotnosti (kolem 20 \% celkové hmotnosti) a signifikantní zlepšení parametrů glycidového metabolismu, triglyceridů i hodnot krevního tlaku. Princip metody spočívá v zavedení gastrostomické kanyly,

Diabetes: Standards of Medical Care in Diabetes-2018. Diabetes care; 41(Suppl 1): S65-S72.

10. Jakicic JM, Rogers RJ, Davis KK, Collins KA. Role of Physical Activity and Exercise in Treating Patients with Overweight and Obesity. Clin Chem. 2018; 64(1): 99-107.

11. Coen PM, Carnero EA, Goodpaster BH. Exercise and Bariatric Surgery: An Effective Therapeutic Strategy. Exerc Sport Sci Rev. 2018 Oct; 46(4): 262-270.

12. Churuangsuk C, Kherouf M, Combet E, Lean M. Low carobohydrate diet or overweight and obesity: a systematic review of the systematic reviews. Obes reviews, 2018; 19(12): 1700-1718. 13. Hainer V, et al. Základy klinické obezitologie. 2. vyd. Praha: Grada Publishing 2011: s 277-280.

14. Šrámková P. Novinky ve farmakoterapii obezity. Gastroent Hepatol 2018; 72(6): 495-500.

15. Melissas J, ErenTaskin H, Peirasmakis D, et al. A Simple Food-Diverting Operation for Type 2 Diabetes Treatment. Preliminary Results in Humans with BMI $28-32 \mathrm{~kg} / \mathrm{m} 2$. Obes Surg. 2017; 27(1): 22-29.

16. Fried M, Dolezalova K, Chambers AP, et al. A novel appro- na kterou se napojí aktivní odsávání a po určité době se odsaje aktivně přibližně 30 \% prijaté potravy. Tak jako u jiných metod bude nutné dlouhodobé sledování většího počtu pacientů, aby bylo možné seriózně tuto metodu zhodnotit. V české obezitologické komunitě je tento výkon zatím akceptován se značnou rezervou.

\section{Závěr}

Léčba obezity není snadná a i přes veškeré úspěchy za poslední desetiletí, které se na tomto poli dosáhly, je zřejmě vzdálený ideál, který téměř před 15 lety definoval Alvarez-Cordero (22). Prál si, abychom v 21. století nemuseli operovat a měli na léčbu jednu zázračnou tabletku. Zázraky se jen tak nedějí, a proto je nutné trpělivě hledat nové postupy v prevenci, nemedikamentózní, medikamentózní i chirurgické léčbě obezity. Místo konzervativních postupů je jasně definované. Endoskopie a chirurgie v současnosti soutěží o místo na pomyslných stupních vítězů. Zatím to vypadá tak, že endoskopické postupy se umístují za konzervativní léčbou a chirurgické intervence zůstávají na vrcholku terapeutické pyramidy.

ach to glycemic control in type 2 diabetes mellitus, partia jejunal diversion: pre-clinical to clinical pathway. BMJ Open Diabetes Res Care. 2017; 5(1): e000431.

17. Machytka E, Bužga M, Zonča P, et al. Partial jejunal diversion using an incisionless magnetic anastomosis system: 1-yea interim results in patients with obesity and diabetes. Gastrointest Endosc. 2017; 86(5): 904-912.

18. Dargent J. Novel Endoscopic Management of Obesity Clin Endos 2016; 49(1): 30-36.

19. Park JM. Role of Malabsorptive Endoscopic Procedures in Obesity Treatment. Clin Endosc 2017; 50: 26-30.

20. Lee HL. Role of Restrictive Endoscopic Procedures in Obesity Treatment Clin Endosc 2017; 50: 17-20.

21. Nyström M, Machytka E, Norén E, et al. Aspiration Therapy As a Tool to Treat Obesity: 1 - to 4-Year Results in a 201-Patient Multi-Center Post-Market European Registry Study. Obes Surg. 2018 [Epub ahead of print] Dostupné z: https://www. ncbi.nlm.nih.gov/pubmed/29388050

22. Alvarez-Cordero R. Will we still be cutting in the 21st century? Obes Surg 2005; 15(10): 1366-1367.

\section{www.medicinapropraxi.cz}

